\title{
Association Between Cannabinoid Receptor-I Gene Polymorphism and the Risk of Diabetic Nephropathy Among Patients with Type 2 Diabetes Mellitus
}

This article was published in the following Dove Press journal: Pharmacogenomics and Personalized Medicine

\author{
Xuelian Zhang' \\ Haiqing Zhu ${ }^{2}$ \\ Xiaoyan Xing ' \\ Chunyu Zhang ${ }^{3}$ \\ 'Department of Endocrinology, China- \\ Japan Friendship Hospital, Beijing 100029 , \\ People's Republic of China; ${ }^{2}$ Department \\ of Endocrinology, Emergency General \\ Hospital, Beijing 100028, People's \\ Republic of China; ${ }^{3}$ Department of \\ Statistical Teaching and Research, China- \\ Japan Friendship Hospital, Beijing 100029 , \\ People's Republic of China
}

Background: The cannabinoid receptor 1 (CNR1) gene polymorphism is reportedly associated with components of metabolic syndrome and coronary artery diseases in patients with type 2 diabetes mellitus (T2DM). We investigated whether the common variant rs10493353 polymorphism is associated with diabetic nephropathy (DN) in T2DM patients.

Patients and Methods: T2DM patients with DN were enrolled as a case group, and patients with only T2DM as a control group. Demographic data and biochemical parameters were collected. The polymerase chain reaction-based restriction fragment length polymorphism technique was used for genotyping. The odds ratio and $90 \%$ confidence interval were calculated to assess the association between genotypes and the risk of DN.

Results: In total, 320 T2DM patients and 320 DN patients were enrolled. Compared with T2DM patients, the DN patients have a significantly larger body mass index (BMI), longer duration of disease, and higher proportions of smokers, drinkers, and hypertension. The risk of DN was significantly decreased by genotypes AA ( $\mathrm{OR}=0.39,95 \% \mathrm{CI}=0.23-0.67)$ and GA $(\mathrm{OR}=0.53,95 \% \mathrm{CI}=0.37-0.75)$ vs $\mathrm{GG}$ (codominant model), GA/AA vs GG (OR=0.49, 95\% $\mathrm{CI}=0.35-0.67$; dominant model), AA vs GG/GA (OR=0.47, 95\% CI $=0.28-0.80$; recessive model), and the A allele ( $\mathrm{OR}=0.52,95 \% \mathrm{CI}=0.40-0.68$; allele model). Multiple logistic regressions still show significant levels. Negative interactions were found between gene and clinical parameters, including drinking, smoking, BMI, and hypertension.

Conclusion: The A allele of CNR1 gene rs10493353 may be a protective factor for DN in T2DM patients. The risk factors of DN can affect the protective role of A allele in the progression of DN.

Keywords: diabetes mellitus, diabetic nephropathy, gene polymorphism, cannabinoid receptor 1

\section{Introduction}

Due to unhealthy eating habits and lifestyles, the global prevalence of diabetes has increased dramatically. Diabetes has become the second major type of diseases after high blood pressure, and has brought heavy living and economic burdens to patients. ${ }^{1}$ Diabetic nephropathy (DN), one of the main chronic microvascular complications of diabetes mellitus, is the primary cause of dialysis in developed countries and the main cause of dialysis in patients with kidney diseases. ${ }^{2,3}$ With the accelerated aging and significant changes in diet and lifestyle in China, the prevalence of diabetes mellitus has increased significantly, and more than $1 / 3$ of patients with type 1 diabetes mellitus (T1DM) and $20 \%$ of patients with type 2
Correspondence: Xiaoyan Xing Department of Endocrinology, ChinaJapan Friendship Hospital, Chaoyang District, Beijing 100029, People's Republic of China

Email 3382648198@qq.com
Pharmacogenomics and Personalized Medicine 2020:13 59|-599 
diabetes mellitus (T2DM) eventually develop to $\mathrm{DN} .{ }^{4} \mathrm{DN}$ is characteristic of glomerular hypertrophy, proteinuria, progressive decrease of glomerular filtration rate (GFR), and renal fibrosis, which lead to the loss of renal function. Intraglomerular hypertension and high filtration are caused by abnormal glucose metabolism, hemodynamics, genetic susceptibility, and other abnormalities. ${ }^{5}$ The diminished renal function caused by DN will shorten the life expectancy and increase the risk of cardiovascular diseases, thereby seriously lowering the quality-of-life. At present, there is no specific effective drug for the treatment of DN. ${ }^{6}$ The progress of DN is mainly delayed by improving lifestyles, controlling blood glucose and blood pressure, and correcting lipid metabolism disorders. The specific molecular mechanism leading to DN is not fully understood. Due to the complex background of metabolic diseases, the prevention and treatment of DN are more challenging than other kidney diseases. DN has become an important scientific and social problem. Therefore, early risk assessment and prevention of DN in T2DM patients are important.

DN is also affected by gene factors in addition to environmental risk factors. Cannabinoid receptor 1 (CNR1) is a polypeptide composed of 473 amino acids encoded by CNR1 genes. It belongs to the inhibitory $\mathrm{G}$ protein coupled receptor family. The rs 10493353 polymorphism (also called G1359A) is reportedly associated with some components of metabolic syndrome, such as decreased high-density lipoprotein cholesterol, obesity, elevated triglyceride, and insulin levels, which are all risk factors of T2DM. ${ }^{7-10}$ This common polymorphism is associated with risk of T2DM. ${ }^{11}$ However, rs 10493353 may not be associated with T2DM, but may contribute the genetic risk of diabetic complications, such as coronary artery disease. ${ }^{12}$ Animal experiments suggest that the blockade of CNR1 can increase the albuminuria level in diabetic mice compared with the controls. ${ }^{13}$ Furthermore, high-glucose stimulates the upregulation of CNR1-related receptor expression, and blockade of CNR1 decreases the urinary 8-isoprostane, renal lipid hydroperoxide, and renal lipid levels. ${ }^{14}$ These results imply that the CNR1-related receptor is involved in the development of DN. Despite the association studies above, no data about the association between rs10493353 polymorphism and DN in T2DM patients are available. In the present study, we investigated whether the rs 10493353 polymorphism is associated with DN in T2DM patients.

\section{Patients and Methods}

\section{Study Population}

We enrolled T2DM patients from the Department of Endocrinology, China-Japan Friendship Hospital, and Department of Endocrinology, Emergency General Hospital from 2018 to 2019. T2DM patients with DN were included as a case group, and T2DM patients without $\mathrm{DN}$ were set as a control group. T2DM was diagnosed according to the criteria recommended by World Health Origination: Diabetic symptoms (so-called typical clinical polydipsia, polyuria, and more food and weight loss), blood glucose $\geq 11.1 \mathrm{~mol} / \mathrm{L}$ at any time or fasting blood glucose $\geq 7.0 \mathrm{~mol} / \mathrm{L}$, or 2-hour postprandial plasma glucose level $\geq 11.1 \mathrm{~mol} / \mathrm{L} .{ }^{15} \mathrm{DN}$ was diagnosed in accordance with the consensus reached by the American Diabetes Association and National Kidney Foundation: GFR $<60 \mathrm{~mL} / \mathrm{min}^{*} 1.73^{2}$ or albumin creatinine ratio $>30 \mathrm{mg} / \mathrm{g}$ lasting for more than 3 months. ${ }^{16,17}$

The following patients were excluded: 1) T1DM; 2) severe cardiac, liver, and renal function failure; 3) drug intoxication, infection and multiple myeloma, macroglobulin, urinary tract infection, ureteral calculi and tumors, renal disease, and other diseases that cause proteinuria; 4) experience of strenuous exercise within 24 hours; 5) historical exposure to radiation; 6) pregnancy or nursing; and 7 ) in relation to another study population. This study was approved by the Ethics Committee of China-Japan Friendship Hospital, and all subjects provided written informed consent. The research has been carried out in accordance with the World Medical Association Declaration of Helsinki.

\section{Data Collection}

Demographic data including gender, age, height, weight, body mass index $(\mathrm{BMI}=$ weight $/$ (height $\times$ height $), \mathrm{kg} / \mathrm{m}^{2}$ ), waist, duration of DM, blood pressure for hypertension diagnosis, and history of medication, smoking, or drinking. Venous blood was collected on an empty stomach at early morning for detection of biochemical parameters: triglyceride (TG), total cholesterol (TC), low-density lipoprotein cholesterol (LDL-C), high-density lipoprotein cholesterol (HDL-C), $\mathrm{HbA} 1 \mathrm{c} \%$, fast blood glucose, creatinine, and albumin for albumin/creatinine ratio. Morning urine was collected for urinary albumin detection. The eGFR was calculated as follows: $186 \times \mathrm{SCr}^{1.154}$, age in years $=$ $-0.203 \times 1.210$ (if black) or $\times 0.742$ (if female). ${ }^{18}$ Hypertension was defined as systolic BP $(\mathrm{SBP}) \geq 140$ 
$\mathrm{mmHg}$ or diastolic $\mathrm{BP}(\mathrm{DBP}) \geqq 90 \mathrm{mmHg}$ or previous intake of anti-hypertensive drug, and BMI $>24$ was judged as overweight. ${ }^{19}$ Smoking was defined as current smoking or previous daily smoking. ${ }^{20}$ Drinking was defined as $2-4$ times a month. ${ }^{21}$

\section{SNP Genotyping}

Another $5 \mathrm{~mL}$ of venous blood was collected for DNA extraction via a Chelex-100 device (Rio-Rad, Hercules, $\mathrm{CA}$ ). The polymerase chain reaction (PCR)-based restriction fragment length polymorphism technique was used. The extracted DNA was stored at $-20^{\circ} \mathrm{C}$, and DNA amplification of a single nucleotide polymorphism (SNP) was performed with primers (forward 5'-TTCACAGGGCCGC AGAAAG-3', reverse 5'-GAGGCATCAGGCTCA CAGA G-3'). Real-time PCR conditions were as follows: $95^{\circ} \mathrm{C}$ for 10 minutes; 40 cycles of $95^{\circ} \mathrm{C}$ for 15 seconds, and $60{ }^{\circ} \mathrm{C}$ for 1 minute; final extension at $72^{\circ} \mathrm{C}$ for 10 minutes. The PCR products were separated by $2 \%$ agarose gel electrophoresis. Results were analyzed using TYPER 4.0.

\section{Statistical Analysis}

All analyses were performed on SPSS 23.0. Continuous data were expressed as mean \pm standard deviation, and compared between cases and controls by independent $t$-test. Category data were expressed as count and percent, and compared by the Chi-square test. The associations between gene polymorphism and the risk of DN were assessed by codominant model (GG/GA/AA), dominant model (GA/AA vs GG), recessive model (AA vs GG/GA), and allele model (A vs G). Univariate and multiple logistic regressions (adjusted for age, gender, smoking, drinking, BMI, hypertension, diuretics, duration of disease) were used to calculate the odds ratio (OR) and their $95 \%$ confidence interval (CI). The multiple comparisons were corrected by the false-positive report probability analysis with a prior probability of 0.01 being assigned to detect an OR of 1.5 (risk allele) or 0.67 (protective allele). Subgroup analysis was performed by gender, hypertension, smoking, drinking, BMI, and diuretics usage. The crossover analysis was used to assess the interaction between gene and environment. The interaction analysis only involved these significant variables in univariate analysis, including smoking, drinking, BMI, and hypertension. $P<0.05$ was considered as the significant level.

\section{Results}

\section{Comparisons of General Characteristics Between Groups}

The comparisons of general characteristics between the case group and the control group are presented in Table 1. In total, $320 \mathrm{~T} 2 \mathrm{DM}$ patients and $320 \mathrm{DN}$ patients were enrolled. No significant differences between groups were found in age $(54.1 \pm 7.0$ vs $53.9 \pm 7.2, P=0.860)$, gender rate (male: $42.2 \%$ vs $49.1 \%, P=0.081$ ), or waist ( 90.4 \pm 9.8 vs $89.7 \pm 9.8, P=0.374)$. The $\mathrm{DN}$ patients compared with the T2DM patients had significantly larger BMI (28.9 \pm 2.2 vs $28.5 \pm 2.3, P=0.031$ ) and longer duration of disease $(6.2 \pm 2.2$ vs $4.5 \pm 2.0, P<0.001)$, and were more likely to be smokers $(32.2 \%$ vs $21.9 \%, P=0.003)$ and drinkers $(35.9 \%$ vs $23.4 \%, P=0.001)$. The hypertension rate was also higher in the DN group than in the T2DM group (33.4\% vs $24.7 \%, P=0.015)$. No significant differences were found in TG $(P=0.230)$, TC $(P=0.466)$, LDL-C $(P=0.931)$, HDL-C ( $P=0.106)$, fast blood glucose $(P=0.409)$, HbA1c $(P=0.194)$, or creatinine $(P=0.301)$. However, eGFR was significantly lower in the DN group than in the T2DM group (62.9 \pm 6.2 vs $74.7 \pm 5.8$, $P<0.001$ ), while the albumin/creatinine ratio was extremely higher in the DN group $(81.9 \pm 14.4$ vs $30.5 \pm 5.1$, $P<0.001)$. We also compared the medication usage between two groups, including angiotensin-converting enzyme inhibitor (ACEI), angiotensin II receptor blocker (ARB), calcium channel blocker (CCB), diuretics, betablocker, alpha-blocker, and lipid-lowering. No significant differences were found in these medications, expect for the diuretics $(35.0 \%$ vs $27.5 \%, P=0.041)$.

\section{Association Between Gene Polymorphism and DN}

Table 2 presents the association between CNR1 gene polymorphism and risk of DN in different genetic models. In the codominant model, the AA $(\mathrm{OR}=0.39,95 \%$ $\mathrm{CI}=0.23-0.67, \quad P=0.001) \quad$ and $\quad \mathrm{GA} \quad(\mathrm{OR}=0.53, \quad 95 \%$ $\mathrm{CI}=0.37-0.75, P<0.001)$ genotypes decreased the risk of DN compared to GG genotype. In the dominant model, the GA/AA genotypes had lower risk of DN than GG genotype $(\mathrm{OR}=0.49,95 \% \mathrm{CI}=0.35-0.67, P<0.001)$. In the recessive model, the AA genotype decreased the risk of $\mathrm{DN}$ compared to $\mathrm{GG} / \mathrm{GA}(\mathrm{OR}=0.47,95 \% \mathrm{CI}=0.28-0.80$, $P=0.006)$. In the allele model, the A allele was a low-risk factor for $\mathrm{DN}(\mathrm{OR}=0.52,95 \% \mathrm{CI}=0.40-0.68, P<0.001)$. Furthermore, multiple logistic regressions were performed. 
Table I Comparisons of General Characteristics Between the DM Group and DN Group

\begin{tabular}{|c|c|c|c|c|}
\hline Parameters & DM Group & DN Group & $t / x^{2}$ & $P$ \\
\hline Age (years) & $53.9 \pm 7.2$ & $54.1 \pm 7.0$ & -0.177 & 0.860 \\
\hline Gender & & & 3.048 & $0.08 I$ \\
\hline Male, n (\%) & I35 (42.2\%) & 157 (49.1\%) & & \\
\hline Female, n (\%) & I 85 (57.8\%) & 163 (50.9\%) & & \\
\hline Waist, cm & $89.7 \pm 9.8$ & $90.4 \pm 9.8$ & -0.890 & 0.374 \\
\hline BMI, $\mathrm{kg} / \mathrm{m}^{2}$ & $28.5 \pm 2.3$ & $28.9 \pm 2.2$ & -2.163 & 0.031 \\
\hline Smoking, n (\%) & 70 (21.9\%) & 103 (32.2\%) & 8.627 & 0.003 \\
\hline Drinking, n (\%) & $75(23.4 \%)$ & 115 (35.9\%) & 11.977 & 0.001 \\
\hline Hypertension, n (\%) & 79 (24.7\%) & 107 (33.4\%) & 5.942 & 0.015 \\
\hline $\mathrm{TG}, \mathrm{mg} / \mathrm{dL}$ & $151.5 \pm 62.3$ & $145.7 \pm 59.9$ & 1.203 & 0.230 \\
\hline $\mathrm{TC}, \mathrm{mg} / \mathrm{dL}$ & $186.4 \pm 32.2$ & $184.6 \pm 32.7$ & 0.730 & 0.466 \\
\hline LDL-C, mg/dL & $122.5 \pm 36.7$ & $122.2 \pm 38.8$ & 0.087 & 0.931 \\
\hline $\mathrm{HDL}-\mathrm{C}, \mathrm{mg} / \mathrm{dL}$ & $47.2 \pm 11.4$ & $45.7 \pm 12.7$ & 1.617 & 0.106 \\
\hline Fast blood glucose, $\mathrm{mg} / \mathrm{dL}$ & $139.3 \pm 20.1$ & $|40.6 \pm 20|$. & -0.827 & 0.409 \\
\hline $\mathrm{HbAlc}, \%$ & $8.1 \pm 1.4$ & $7.9 \pm 1.5$ & 1.300 & 0.194 \\
\hline Creatinine, $\mathrm{mg} / \mathrm{dL}$ & $1 . I \pm 0.3$ & $1.1 \pm 0.3$ & 1.305 & 0.301 \\
\hline eGFR, $\mathrm{mL} / \mathrm{min} * 1.73 \mathrm{~m}^{2}$ & $74.7 \pm 5.8$ & $62.9 \pm 6.2$ & 2.882 & $<0.001$ \\
\hline Albumin/Creatinine, mg/g & $81.9 \pm 14.4$ & $30.5 \pm 5.1$ & -60.368 & $<0.001$ \\
\hline Duration of disease, year & $4.5 \pm 2.0$ & $6.2 \pm 2.2$ & -9.917 & $<0.001$ \\
\hline \multicolumn{5}{|l|}{ Medication usage, n (\%) } \\
\hline ACEI & 50 (15.6\%) & $5 \mathrm{I}(15.9 \%)$ & 0.012 & 0.914 \\
\hline ARB & $159(49.7 \%)$ & 140 (43.8\%) & 2.266 & 0.132 \\
\hline $\mathrm{CCB}$ & 92 (28.7\%) & 86 (26.9\%) & 0.280 & 0.597 \\
\hline Diuretics & 112 (35.0\%) & 88 (27.5\%) & 4.189 & 0.041 \\
\hline$\beta$-blocker & III (34.7\%) & 101 (31.6\%) & 0.705 & 0.401 \\
\hline$\alpha$-blocker & $56(17.5 \%)$ & $59(18.4 \%)$ & 0.095 & 0.757 \\
\hline Lipid-lowering & 161 (50.3\%) & 162 (50.6\%) & 0.006 & 0.937 \\
\hline
\end{tabular}

Abbreviations: DM, diabetes mellitus; DP, diabetic nephropathy; BMI, body mass index; SBP, systolic blood pressure; DBP, diastolic blood pressure; eGFR, estimated glomerular filtration rate; TG, Triglyceride; TC, total cholesterol; LDL-C, low-density lipoprotein cholesterol; HDL, high-density lipoprotein cholesterol; ACEI, angiotensinconverting enzyme inhibitor; ARB, angiotensin II receptor blocker; CCB, calcium channel blocker.

The adjusted results still show significant levels (Table 2). With the corrected multiple tests, the false-positive report probability was analyzed (Table 3 ). Results indicated the effect of SNP remained noteworthy with a priority of 0.1 .

Subgroup analyses were performed to assess the differential effect of clinical parameters on the DN associated with the gene polymorphism. Generally, the AA genotype still led to low risk of DN in all subgroups. Gender, hypertension, smoking, drinking, BMI, and diuretics all affected the association between gene polymorphism and the risk of DN in some gene models, including GA vs GG and AA vs GA/GG of gender, hypertension, smoking, or drinking.

For patients with $\mathrm{BMI}>24$, the A allele was not associated with the risk of $\mathrm{DN}$ (A vs G: $\mathrm{OR}=0.93,9 \%$ $\mathrm{CI}=0.55-1.57, P=0.782)$. The details are presented in Table 4.

\section{Interaction Analysis}

The interactions of gene with smoking, drinking, hypertension, or BMI were investigated using crossover analysis. The AA and GA genotype was found in a negative interaction with smoking for the risk of DN. Only smoking was associated with the risk of DN compared to those without A allele or smoking (OR=1.94, 95\% $\mathrm{CI}=1.21-3.069)$, while the $\mathrm{A}$ allele reduced the risk of DN compared to patients without A allele or smoking (AA: $\mathrm{OR}=0.43,95 \% \mathrm{CI}=0.23-0.79$ ), and the association was insignificant in patients with $\mathrm{A}$ allele and smoking. Both the A allele and only drinking were associated with DN. The A allele lowered the risk of DN (AA: $O R=0.37$, 95\% $\mathrm{CI}=0.19-0.73$; $\mathrm{GA}: \mathrm{OR}=0.54,95 \% \mathrm{CI}=0.35-0.82$ ), and smoking increased the risk of DN. Moreover, smoking weakened the association between gene and DN (AA: $\mathrm{OR}=0.70, \quad 95 \% \quad \mathrm{CI}=0.30-1.65 ; \quad \mathrm{GA}: \quad \mathrm{OR}=1.00, \quad 95 \%$ 
Table 2 Association Between CNRI Gene Polymorphism and Risk of DN in Different Genetic Model

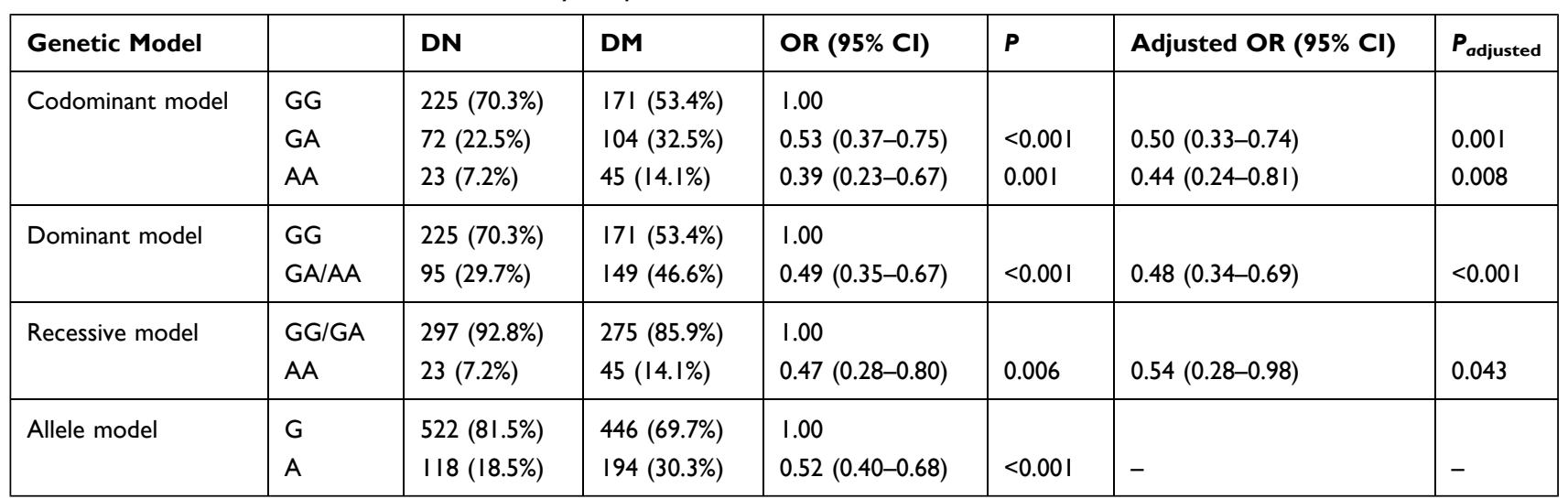

Note: Adjusted for age, gender, smoking, drinking. BMI, hypertension, diuretics, duration of disease.

Abbreviations: DM, diabetes mellitus; $\mathrm{DN}$, diabetic nephropathy; $\mathrm{OR}$, odds ratio; $\mathrm{Cl}$, confidence interval.

Table 3 False-Positive Reports Probability Values of Associations Between Gene and DN

\begin{tabular}{|l|l|l|l|l|l|}
\hline Genetical Model & OR (95\% Cl) & Power & \multicolumn{2}{l|}{ Prior Probability } \\
\cline { 3 - 6 } & & & $\mathbf{0 . 2}$ & $\mathbf{0 . 1}$ & $\mathbf{0 . 0 1}$ \\
\hline GA vs GG & $0.53(0.37-0.75)$ & 0.937 & 0.002 & 0.004 & 0.044 \\
AA vs GG & $0.39(0.23-0.67)$ & 0.929 & 0.021 & 0.045 & 0.343 \\
GA/AA vs GG & $0.49(0.35-0.67)$ & 0.992 & 0.001 & 0.002 & 0.024 \\
AA vs GA/GG & $0.47(0.28-0.80)$ & 0.792 & 0.019 & 0.042 & 0.001 \\
G vs A & $0.52(0.40-0.68)$ & 0.998 & $<0.001$ & 0.010 \\
\hline
\end{tabular}

$\mathrm{CI}=0.53-1.88$ ). For patients with $\mathrm{BMI}>24$, BMI seemingly was not related to the risk of $\mathrm{DN}$, and the AA genotype decreased the risk of $\mathrm{DN}$. A negative interaction was identified between AA genotype and BMI for the elevated risk of $\mathrm{DN}(\mathrm{OR}=1.25,95 \% \mathrm{CI}=0.36-4.36)$. No interaction was found between GA genotype and BMI for susceptibility to DN. Similarly, the A allele was associated with the risk of $\mathrm{DN}$, and insignificant interactions were found between AA $(\mathrm{OR}=1.04,9 \% \mathrm{CI}=0.48-2.25) / \mathrm{GA}(\mathrm{OR}=1.00$, 95\% $\mathrm{CI}=0.54-1.82)$ and hypertension for the decreased risk of DN. The details are presented in Table 5.

\section{Discussion}

1) The $A$ allele has lower frequency in the $D N$ patients than in the DM patients. 2) The A allele of CNR1 gene is associated with a decreased risk of $\mathrm{DN}$ in T2DM patients. 3) Subgroup analysis suggests that gender, hypertension, smoking, drinking, BMI, or diuretics does not affect the association between gene polymorphism and the risk of DN. 4) Negative interactions exist between the CNR1 gene and some parameters for the increased risk of DN, including drinking, smoking, BMI, and hypertension. To the best of our knowledge, this is the first study on the association between rs10493353 of CNR1 gene and the risk of DN.

$\mathrm{DN}$ is one of the major microvascular complications of diabetes mellitus and the primary cause of end-stage renal disease. $^{22}$ The DN ratio caused by T2DM accounts for the vast majority. Due to its inconspicuous early symptoms and limited clinical treatment methods, most patients rapidly progress to chronic renal failure, which become heavy social, medical, and economic burdens. ${ }^{23}$ Therefore, it is of great importance to identify other factors that may affect the progress of DN. A previous study confirms that $\mathrm{DN}$ is induced by the combination of genetic and environment factors. ${ }^{24}$ The present study indicates that the A allele level is lower in the T2DM group than in the DN group, and univariate and multiple logistic regressions show that the AA genotype is significantly related to a decreased risk of DN in T2DM patients. Our results provide important evidence for the role of rs10493353 (G/A) polymorphism in the progression of DN. Reportedly, the rs10493353 (also called G1359A) is involved in the mechanism of metabolic syndromes. Compared with GG genotype, patients with the AA genotype have lower BMI, blood pressure, and insulin resistance. ${ }^{7}$ A previous study suggests that the endogenous 


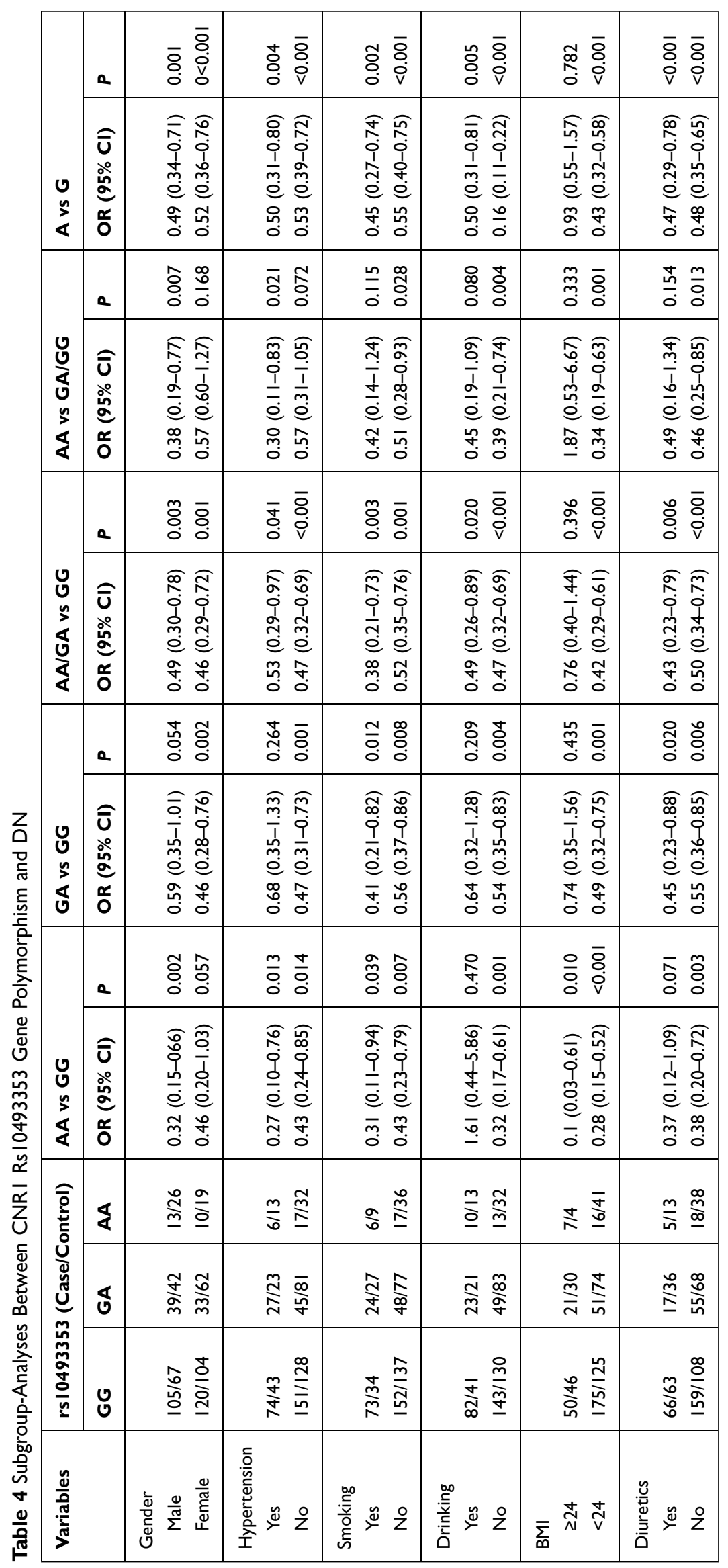


Table 5 Interactions Between Gene and Environmental Factors Analysis

\begin{tabular}{|c|c|c|c|c|c|}
\hline Gene & Environment & Case & Control & OR (95\% Cl) & Reflecting Information \\
\hline $\begin{array}{l}\text { AA/GG } \\
- \\
- \\
+ \\
+\end{array}$ & $\begin{array}{l}\text { Smoking } \\
- \\
+ \\
- \\
+\end{array}$ & $\begin{array}{l}152 \\
73 \\
17 \\
6\end{array}$ & $\begin{array}{l}137 \\
34 \\
36 \\
9\end{array}$ & $\begin{array}{l}1.00 \\
1.94(1.21-3.09) \\
0.43(0.23-0.79) \\
0.60(0.21-1.73)\end{array}$ & $\begin{array}{l}E(-), \text { the role of } G \\
E(+) \text {, the role of } G \\
G(-) \text {, the role of } E \\
G(+) \text {, the role of } E\end{array}$ \\
\hline $\begin{array}{l}\text { GA/GG } \\
- \\
- \\
+ \\
+\end{array}$ & $\begin{array}{l}\text { Smoking } \\
- \\
+ \\
- \\
+\end{array}$ & $\begin{array}{l}152 \\
73 \\
48 \\
24\end{array}$ & $\begin{array}{l}137 \\
34 \\
77 \\
27\end{array}$ & $\begin{array}{l}1.00 \\
1.94(1.21-3.09) \\
0.56(0.37-0.86) \\
0.80(0.44-1.45)\end{array}$ & $\begin{array}{l}E(-) \text {, the role of } G \\
E(+) \text {, the role of } G \\
G(-) \text {, the role of } E \\
G(+), \text { the role of } E\end{array}$ \\
\hline $\begin{array}{l}\text { AA/GG } \\
- \\
- \\
+ \\
+\end{array}$ & $\begin{array}{l}\text { Drinking } \\
- \\
+ \\
- \\
+\end{array}$ & $\begin{array}{l}143 \\
82 \\
13 \\
10\end{array}$ & $\begin{array}{l}130 \\
41 \\
32 \\
13\end{array}$ & $\begin{array}{l}1.00 \\
1.82(1.17-2.83) \\
0.37(0.19-0.73) \\
0.70(0.30-1.65)\end{array}$ & $\begin{array}{l}E(-), \text { the role of } G \\
E(+, \text { the role of } G \\
G(-) \text {, the role of } E \\
G(+), \text { the role of } E\end{array}$ \\
\hline $\begin{array}{l}\text { GA/GG } \\
- \\
- \\
+ \\
+\end{array}$ & $\begin{array}{l}\text { Drinking } \\
- \\
+ \\
- \\
+\end{array}$ & $\begin{array}{l}143 \\
82 \\
49 \\
23\end{array}$ & $\begin{array}{l}130 \\
41 \\
83 \\
21\end{array}$ & $\begin{array}{l}1.00 \\
1.82(1.17-2.83) \\
0.54(0.35-0.82) \\
1.00(0.53-1.88)\end{array}$ & $\begin{array}{l}E(-) \text {, the role of } G \\
E(+) \text {, the role of } G \\
G(-) \text {, the role of } E \\
G(+) \text {, the role of } E\end{array}$ \\
\hline $\begin{array}{l}\text { AA/GG } \\
- \\
- \\
+ \\
+\end{array}$ & $\begin{array}{l}\text { BMI } \\
- \\
+ \\
- \\
+\end{array}$ & $\begin{array}{l}175 \\
50 \\
16 \\
7\end{array}$ & $\begin{array}{l}125 \\
46 \\
41 \\
4\end{array}$ & $\begin{array}{l}1.00 \\
0.78(0.49-1.23) \\
0.28(0.15-0.52) \\
1.25(0.36-4.36)\end{array}$ & $\begin{array}{l}E(-) \text {, the role of } G \\
E(+) \text {, the role of } G \\
G(-) \text {, the role of } E \\
G(+) \text {, the role of } E\end{array}$ \\
\hline $\begin{array}{l}\text { GA/GG } \\
- \\
- \\
+ \\
+\end{array}$ & $\begin{array}{l}\text { BMI } \\
- \\
+ \\
- \\
+\end{array}$ & $\begin{array}{l}175 \\
50 \\
51 \\
21\end{array}$ & $\begin{array}{l}125 \\
46 \\
41 \\
30\end{array}$ & $\begin{array}{l}1.00 \\
0.78(0.49-1.23) \\
0.89(0.55-1.42) \\
0.50(0.27-0.91)\end{array}$ & $\begin{array}{l}E(-), \text { the role of } G \\
E(+) \text {, the role of } G \\
G(-) \text {, the role of } E \\
G(+) \text {, the role of } E\end{array}$ \\
\hline $\begin{array}{l}\text { AA/GG } \\
- \\
- \\
+ \\
+\end{array}$ & $\begin{array}{l}\text { Hypertension } \\
- \\
+ \\
- \\
+\end{array}$ & $\begin{array}{l}151 \\
74 \\
17 \\
16\end{array}$ & $\begin{array}{l}128 \\
43 \\
32 \\
13\end{array}$ & $\begin{array}{l}1.00 \\
1.46(0.94-2.27) \\
0.45(0.24-0.85) \\
1.04(0.48-2.25)\end{array}$ & $\begin{array}{l}E(-), \text { the role of } G \\
E(+) \text {, the role of } G \\
G(-) \text {, the role of } E \\
G(+) \text {, the role of } E\end{array}$ \\
\hline $\begin{array}{l}\text { GA/GG } \\
- \\
- \\
+ \\
+\end{array}$ & $\begin{array}{l}\text { Hypertension } \\
- \\
+ \\
- \\
+\end{array}$ & $\begin{array}{l}151 \\
74 \\
45 \\
27\end{array}$ & $\begin{array}{l}128 \\
43 \\
81 \\
23\end{array}$ & $\begin{array}{l}1.00 \\
1.46(0.94-2.27) \\
0.47(0.31-0.73) \\
1.00(0.54-1.82)\end{array}$ & $\begin{array}{l}E(-), \text { the role of } G \\
E(+) \text {, the role of } G \\
G(-) \text {, the role of } E \\
G(+) \text {, the role of } E\end{array}$ \\
\hline
\end{tabular}

opioid system may play a role in some metabolic events associated with potential obesity, such as plasma $\beta$ endorphin related to marked $\beta$-cell and $\alpha$-cell hormonal reactivity in subjects at high risk for obesity. The opioid receptor blockade by naloxone may revert the hyperglycemic response and exaggerate/3- and a-cell production secondary to p-endorphin infusion in obese subjects, and essentially decrease both plasma insulin and glucose levels. ${ }^{25}$ Like the opioid system, the blockade of CNR1 receptor not only facilitates weight loss, but also improves insulin sensitivity and clinical measures of lipid homeostasis. $^{8}$ 
On the contrary, the HDL-C level was elevated in patients with AA genotype. The AA genotype may be associated with a decreased risk of metabolic syndromes. ${ }^{9}$ It is well-known that the components of metabolic syndromes are risk factors of T2DM and lead to the progression of T2DM. ${ }^{26,27}$ Our study demonstrates that the AA genotype reduces the risk of DN. Probably, the variation of CNR1 gene decreases the expression or activity of CNR1 receptor, which reduces stimulation to the endocannabinoid receptor by endocannabinoid. The endocannabinoid system affects the dietary behavior of patients through central and peripheral mechanisms. The elevated expression of CNR1 will directly increase the appetite of patients, which also explains the influence of higher mRNA expression in patients with GG genotype. ${ }^{28}$ Previous studies show that another genetic locus $(1260 \mathrm{G}>\mathrm{A})$ plays an important role in the clinical outcomes of early-stage T2DM treated with liraglutide. Mean levels of BMI, FPG, and HbAlc decrease more significantly in GA/AA genotype patients than GG genotype patients $(P<0.05)$. Mean levels of BMI, FPG, 2hPG, and $\mathrm{HbA} 1 \mathrm{c}$ decrease significantly after treatment in GA/AA and GG genotype patients. The mean mRNA expression of CNR1 in GG genotype patients is significantly higher than in GA/AA genotype patients. The AA genotype reduces the insulin resistance and weight, which affect the clinical efficacy of liraglutide. ${ }^{29}$ Since the rs 10493353 polymorphism is also associated with metabolic components such as G1260A, the AA genotype of rs10493353 may affect the development of DN in T2DM patients through a similar mechanism. In recent years, it is suggested that the endocannabinoid system affects the secretion function of the pancreas. The cannabinoids show pharmacologic action under the combination of CNR1 and CNR2. In-vivo experiments show that CNR1 is expressed in A cells. The CNR1 agonist (anandamide and arachidonylcyclopropylamide) can exhibit the cytosolic $\mathrm{Ca}$ oscillation induced by glucose, and inhibit the insulin secretion. The blockade of CNR1 enhances the insulin receptor signaling and elevates the A cell proliferation through gene and pharmacology. ${ }^{30}$ The blood glucose level decreases, and A-cell proliferation and insulin receptor signaling are enhanced after CNR1 antagonism treatment in mice. These results indicate DNR1 can be a therapeutic target for DN. ${ }^{31}$ Our study also indicates some negative interactions between A allele and environmental factors. Specifically, smoking, drinking, overweight, and hypertension all affect the protective role of A allele in the development of DN, meaning that these metabolism-related risk factors will increase the risk of DN with GG genotype. This is because the GG genotype accounts for the majority of patients and increases the mRNA expression. The blockade for CNR1 can be an effective treatment method. ${ }^{32-34}$

Our study has several limitations. First, despite the sufficient statistical power (more than $90 \%$ ), the subgroup analyses have some restrictions because of the small sample size. Second, this study was performed in the populations of northern China, the results should be explained cautiously in other population settings. Third, we did not perform genotyping in normal healthy controls because of our study objective and the fact that previous studies have confirmed the association between rs10493353 polymorphism and T2DM. Finally, we did not explore the specific molecular mechanism, so further research is needed.

In conclusion, the rs 10493353 polymorphism of the CNR1 gene is associated with DN in T2DM patients, and the A allele decreases the risk of DN. Some environmental factors can counteract the effect of gene in the progression of DN. The rs $10493353 \mathrm{G} / \mathrm{A}$ polymorphism may be an independent marker of DN in T2DM patients. The blockade of CNR1 can be used for treatment of DN in T2DM patients.

\section{Disclosure}

The authors have no conflicts of interest to declare.

\section{References}

1. Bowe B, Xie Y, Li T, Yan Y, Xian H, Al-Aly Z. The 2016 global and national burden of diabetes mellitus attributable to PM2.5 air pollution. Lancet Planet Health. 2018;2(7):e301-e312. doi:10.1016/ S2542-5196(18)30140-2

2. Abou-Hany HO, Atef H, Said E, Elkashef HA, Salem HA. Crocin mediated amelioration of oxidative burden and inflammatory cascade suppresses diabetic nephropathy progression in diabetic rats. Chem Biol Interact. 2018;284:90-100. doi:10.1016/j.cbi.2018.02.001

3. Chen H, Wang DG, Yuan L, et al. Clinical characteristics of patients with diabetic nephropathy on maintenance hemodialysis: a multicenter cross-sectional survey in Anhui Province, Eastern China. Chin Med $J$ (Engl). 2016;129(11):1291-1297. doi:10.4103/0366-6999.182832

4. Zhang XX, Kong J, Yun K. Prevalence of diabetic nephropathy among patients with Type 2 diabetes mellitus in china: a meta-analysis of observational studies. J Diabetes Res. 2020;2020:2315607. doi:10. $1155 / 2020 / 2315607$

5. Ayodele OE, Alebiosu CO, Salako BL. Diabetic nephropathy-a review of the natural history, burden, risk factors and treatment. $J$ Natl Med Assoc. 2004;96(11):1445-1454.

6. Kelley K, Aricak OT, Light RP, Agarwal R. Proteinuria is a determinant of quality of life in diabetic nephropathy: modeling lagged effects with path analysis. Am J Nephrol. 2007;27(5):48 8-494. doi:10.1159/000106672

7. de Luis DA, Gonzalez SM, Aller R, Izaola O, Conde R. Influence of G1359A polymorphism of the cannabinoid receptor gene on anthropometric parameters and insulin resistance in women with obesity. Metabolism. 2011;60(2):272-276. doi:10.1016/j.metabol.2010.01.028 
8. Baye TM, Zhang Y, Smith E, et al. Genetic variation in cannabinoid receptor 1 (CNR1) is associated with derangements in lipid homeostasis, independent of body mass index. Pharmacogenomics. 2008;9 (11):1647-1656. doi:10.2217/14622416.9.11.1647

9. de Luis DA, Aller R, Gonzalez SM, Conde R, Izaola O, de la Fuente B. Genetic variation in the cannabinoid receptor gene (CNR1) (G1359A polymorphism) and their influence on anthropometric parameters and metabolic parameters under a high monounsaturated vs. high polyunsaturated fat hypocaloric diets. J Nutr Biochem. 2013;24(8):1431-1435. doi:10.1016/j.jnutbio.2012.12.001

10. Luis DA, Gonzalez SM, Aller R, et al. [G1359A polymorphism of the cannabinoid receptor gene (CNR1) on anthropometric parameters and cardiovascular risk factors in patients with morbid obesity]. Nutr Hosp. 2009;24(6):688-692. Chinese.

11. Stancakova A, Laakso M. Genetics of Type 2 diabetes. Endocr Dev. 2016;31:203-220. doi:10.1159/000439418

12. Wang R, Hu W, Qiang L. G1359A polymorphism in the cannabinoid receptor-1 gene is associated with the presence of coronary artery disease in patients with type 2 diabetes. J Investig Med. 2012;60 (1):44-48. doi:10.2310/JIM.0b013e31823d79a4

13. Barutta F, Corbelli A, Mastrocola R, et al. Cannabinoid receptor 1 blockade ameliorates albuminuria in experimental diabetic nephropathy. Diabetes. 2010;59(4):1046-1054. doi:10.2337/db091336

14. Nam DH, Lee MH, Kim JE, et al. Blockade of cannabinoid receptor 1 improves insulin resistance, lipid metabolism, and diabetic nephropathy in db/db mice. Endocrinology. 2012;153(3):1387-1396. doi:10. 1210/en.2011-1423

15. Benhalima K, Van Crombrugge P, Moyson C, et al. Risk factor screening for gestational diabetes mellitus based on the $2013 \mathrm{WHO}$ criteria. Eur J Endocrinol. 2019;180(6):353-363. doi:10.1530/EJE19-0117

16. Gross JL, de Azevedo MJ, Silveiro SP, Canani LH, Caramori ML, Zelmanovitz T. Diabetic nephropathy: diagnosis, prevention, and treatment. Diabetes Care. 2005;28(1):164-176. doi:10.2337/diacare. 28.1.164

17. American Diabetes Association. 11. Microvascular complications and foot care: standards of medical care in diabetes-2020. Diabetes Care. 2020;43(Suppl 1):S135-S151. doi:10.2337/dc20-S011.

18. Levey AS, Coresh J, Balk E, et al. National Kidney Foundation practice guidelines for chronic kidney disease: evaluation, classification, and stratification. Ann Intern Med. 2003;139(2):137-147. doi:10.7326/0003-4819-139-2-200307150-00013

19. Wang Z, Chen Z, Zhang L, et al. Status of hypertension in china: results from the China hypertension survey, 2012-2015. Circulation. 2018;137 (22):2344-2356. doi:10.1161/CIRCULATIONAHA.117.032380

20. Song J, Zhang H, Zhou H, Li T, Deng Y. [Association between polymorphism of ATP2B1 gene, its interaction with smoking and essential hypertension -a case-control study]. Zhonghua Liu Xing Bing Xue Za Zhi. 2014;35(5):588-592. Chinese.
21. Eriksen BO, Mathisen UD, Melsom T, et al. The role of cystatin C in improving GFR estimation in the general population. Am J Kidney Dis. 2012;59(1):32-40. doi:10.1053/j.ajkd.2011.09.001

22. Magee C, Grieve DJ, Watson CJ, Brazil DP. Diabetic nephropathy: a tangled web to unweave. Cardiovasc Drugs Ther. 2017;31(5-6):579-592. doi:10.1007/s10557-017-6755-9

23. Kopel J, Pena-Hernandez C, Nugent K. Evolving spectrum of diabetic nephropathy. World J Diabetes. 2019;10(5):269-279. doi:10.42 39/wjd.v10.i5.269

24. Tripathi YB, Yadav D. Diabetic nephropathy: causes and managements. Recent Pat Endocr Metab Immune Drug Discov. 2013;7(1):57-64. doi:10.2174/187221413804660971

25. Cozzolino D, Sessa G, Salvatore T, et al. The involvement of the opioid system in human obesity: a study in normal weight relatives of obese people. J Clin Endocrinol Metab. 1996;81(2):713-718. doi:10. 1210/jcem.81.2.8636293

26. Palmer MK, Toth PP. Trends in lipids, obesity, metabolic syndrome, and diabetes mellitus in the United States: an NHANES analysis (2003-2004 to 2013-2014). Obesity (Silver Spring). 2019;27 (2):309-314. doi:10.1002/oby.22370

27. Bozkurt B, Aguilar D, Deswal A, et al. Contributory risk and management of comorbidities of hypertension, obesity, diabetes mellitus, hyperlipidemia, and metabolic syndrome in chronic heart failure: a scientific statement from the american heart association. Circulation. 2016;134(23):e535-e578. doi:10.1161/CIR.00000000 00000450

28. Jager G, Witkamp RF. The endocannabinoid system and appetite: relevance for food reward. Nutr Res Rev. 2014;27(1):172-185. doi:10.1017/S0954422414000080

29. Ren LJ, Wang JJ, Ma HL, Hou HJ, Sima PP, Song RB. Influence of cannabinoid Receptor 1 gene polymorphisms on the clinical outcomes of early-stage Type 2 diabetes mellitus treated with liraglutide. Chin General Prac. 2020;23(17):2152-2155.

30. Nakata M, Yada T. Cannabinoids inhibit insulin secretion and cytosolic $\mathrm{Ca} 2+$ oscillation in islet beta-cells via $\mathrm{CB} 1$ receptors. Regul Pept. 2008;145(1-3):49-53. doi:10.1016/j.regpep.2007.08.009

31. Kim W, Doyle ME, Liu Z, et al. Cannabinoids inhibit insulin receptor signaling in pancreatic beta-cells. Diabetes. 2011;60(4):1198-1209. doi: $10.2337 / \mathrm{db} 10-1550$

32. Keri KC, Samji NS, Blumenthal S. Diabetic nephropathy: newer therapeutic perspectives. J Community Hosp Intern Med Perspect. 2018;8(4):200-207. doi:10.1080/20009666.2018.1500423

33. Di Marzo V. New approaches and challenges to targeting the endocannabinoid system. Nat Rev Drug Discov. 2018;17(9):623-639. doi:10.1038/nrd.2018.115

34. Pacher P, Batkai S, Kunos G. The endocannabinoid system as an emerging target of pharmacotherapy. Pharmacol Rev. 2006;58 (3):389-462. doi:10.1124/pr.58.3.2
Pharmacogenomics and Personalized Medicine

\section{Publish your work in this journal}

Pharmacogenomics and Personalized Medicine is an international, peer-reviewed, open access journal characterizing the influence of genotype on pharmacology leading to the development of personalized treatment programs and individualized drug selection for improved safety, efficacy and sustainability. This journal is indexed on the American Chemical Society's Chemical Abstracts Service (CAS). The manuscript management system is completely online and includes a very quick and fair peer-review system, which is all easy to use. Visit http://www.dovepress.com/testimonials.php to read real quotes from published authors. 